\title{
Experimentally induced intravaginal Tritrichomonas foetus infection in a mouse model $^{1}$
}

\author{
Pedro Soto ${ }^{2 *}$, Hilda María Echevarría ${ }^{2}$, Cristina Esther Monteavaro ${ }^{2}$ and \\ María del Carmen Catena ${ }^{2}$
}

\begin{abstract}
Soto P., Echevarría H.M., Monteavaro C.E. \& Catena M.C. 2005. [Experimentally induced intravaginal Tritrichomonas foetus infection in a mouse model.] Pesquisa Veterinária Brasileira 25(4):225-230. Laboratory of Clinical and Experimental Microbiology, Facultad de Ciencias Veterinarias, UNCPBA, Pinto 399, Tandil (7000), Buenos Aires, Argentina. E-mail: psoto@vet.unicen.ar

The interest to develop research on the host-parasite relationship in bovine tritrichomonosis has accomplished the use of experimental models alternative to cattle. The BALB/c mouse became the most appropriate species susceptible to vaginal Tritrichomonas foetus infection requiring previous estrogenization. For the need of an experimental model without persistent estrogenization and with normal estrous cycles, the establishment and persistence of vaginal infection on BALB/c mouse with different concentrations of T. foetus in two experimental groups was evaluated. Group A was treated with $5 \mathrm{mg}$ of $\beta$-estradiol 3-benzoate to synchronize the estrous, 48 hours before the T. foetus vaginal inoculation, and Group B was inoculated in natural estrus. At 5-7 days after treatment, estrogenic effect decreased allowing all animals to cycle regularly during the experiment. From the first week post-infection, samples of vaginal mucus were taken from all animals during 34 weeks, in order to evaluate the course of infection and the stage of the estrus cycle. Group A showed 93.6\% of infected animals, and Group B showed 38\%. Different doses of T. foetus were assayed to establish the vaginal infection, with a persistence of 34 weeks. Although different behavior was observed in each subgroup belonging to either Group A or Group B, there were no significant differences among the infecting doses used. The b-estradiol 3-benzoate treatment had a favorable effect on the establishment of the infection $(\mathrm{P}<0.0001)$, but it did not influence its persistence $(\mathrm{P}=0.1097)$. According to the results, an experimental mouse model is presented, appropriate for further studies on mechanisms of pathogenicity, immune response, protective evaluation of immunogen and therapeutic effect of drugs.
\end{abstract}

INDEX TERMS: Tritrichomonas foetus, mouse model, experimental tritrichomonosis.

\begin{abstract}
RESUMO.- [Infecção experimental intravaginal com Tritrichomonas foetus em modelo camundongo.] A necessidade de esclarecer a relação agente-hospedeiro na tricomoníase bovina deu motivo para o uso de modelos experimentais alternativos ao bovino. $\mathrm{O}$ camundongo BALB/c resultou como espécie mais adequada para a infeção vaginal com Tritrichomonas foetus, requerendo uma estrogenização prévia. Visando a necessidade de um modelo experimental sem estrogenização persistente e com ciclos estrais normais, foi avaliada a instalação e persistência da
\end{abstract}

\footnotetext{
${ }^{1}$ Received on June 17, 2005.

Accepted for publication on August 15, 2005.

2 Laboratory of Clinical and Experimental Microbiology, Facultad de Ciencias Veterinarias, Universidad Nacional del Centro (UNCPBA), Pinto 399, Tandil (7000), Buenos Aires, Argentina. *Author for correspondnnce. E-mail: psoto@vet.unicen.ar
}

infeção vaginal no camundongo BALB/c com diferentes quantidades de T. foetus, em dois grupos experimentais. O Grupo A foi tratado com $5 \mu \mathrm{g}$ de 3 -benzoato de beta estradiol, para sincronizar o estro, $48 \mathrm{~h}$ antes da inoculação vaginal com $T$. foetus, e o Grupo B foi inoculado durante o estro natural. O efeito do 3benzoato de beta estradiol decresceu gradualmente. A totalidade dos animais ciclaram regularmente após 5-7 dias pós-tratamento. Após a primeira semana pós-infecção, todos os animais foram amostrados durante 34 semanas, para avaliar o andamento da infeção vaginal e o estádio de cío. $O$ Grupo A apresentou 93,6\% de animais infetados e o Grupo B 38\%. Com diferentes dosagens de T. foetus se obteve a instalação e persistência da infecção vaginal durante 34 semanas. Embora tenham-se registrados diferentes comportamentos entre cada um dos lotes dos Grupos A e B, não houveram diferenças significativas entre as doses infectantes. $\mathrm{O}$ tratamento com 3-benzoato de beta 
estradiol teve efeito favorável na instalação da infecção $(\mathrm{P}<0,0001)$, porém não teve influência na persistência $(\mathrm{P}=$ $0,1097)$. Em função dos resultados obtidos, apresenta-se um modelo experimental em camundongo, adequado para aprofundar estudos sobre mecanismos de patogenicidade, resposta imune, avaliação protetora de imunógenos e o efeito terapêutico de fármacos.

TERMOS DE INDEXAÇÃO: Tritrichomonas foetus, modelo camundongo, tricomoníase experimental.

\section{INTRODUCTION}

The genital bovine trichomoniasis (GBT) or bovine tritrichomonosis (BT) is a venereal disease caused by the flagellated protozoon Tritrichomonas foetus. In countries where cattle are extensively raised with natural service, it is an endemic disease, causing reproduction failures and important economic losses (Clark et al. 1983, Goodger \& Skirrow 1986, Rae 1989).

The first link between these protozoa and bovine infertility was made in France (Kunstler 1888). Since then, many investigations on trichomonosis were focused on epidemiology, pathogenesis and disease control through observational studies. At present due to molecular biology development, the scientific interest is focused on the immunopathogenic process, taking into account factors inherent to host-parasite relationship such as, characterization of immune response, pathogenic and antigenic evaluation of $T$. foetus strains, virulence factors and studies on T. foetus antigens as probable vaccines.

In bulls infected with T. foetus the protozoon behaves as a commensal of the preputial and penile epithelial surface, being considered an asymptomatic carrier for life (Honigberg 1978, Skirrow \& BonDurant 1988).

Female cattle are infected during the estrus period. Following infection, the parasites colonize the reproductive tract mucosa, where the adherence of the parasite to the epithelial cells is important. During this period, an increase in keratinization of the vaginal epithelium is produced, and these cells are the favorite target for the adherence of T. foetus in the initial stage of colonization (Corbeil et al. 1989). This infection is clinically manifested by means of reproductive failure as a consequence of histopathological changes in the reproductive tract, showing different degrees of vaginitis, cervicitis, endometritis and placentitis, associated with embryo or fetal loss (Parsonson et al. 1976, Rhyan et al. 1988). The infection in the reproductive tract is variably lasting for 1-5 months (Parsonson et al. 1976, BonDurant 1985, Skirrow \& BonDurant 1988, Soto \& Parma 1989). It has been curiously observed in BT that both gestation and infection are initiated at the same time, coexisting during some time until the lesions in the reproductive tract prevent the continuity of pregnancy. Histopathological changes are shown 63-74 days post-infection, and the most severe lesions appear at 90 days, followed by fetal death (Parsonson et al. 1976, Corbeil et al. 1989, Anderson et al. 1996). In female cattle, the infection induces an immune response at systemic level, and in the reproductive tract allows in many cases elimination of the protozoa before 4-5 months post-infection (Soto \& Parma 1989, Skirrow \& BonDurant 1990). Nevertheless, in some situations the female remains infected for more than a year and is then the cause for infection of the herd (Morgan 1944, Skirrow 1987).

The persistence of infection depends on multiple intrinsic factors of the host-parasite relationship. There rose interest of many researchers on the pathogenic capacity of T. foetus strains (Hook et al. 1995, Soto et al. 1997), the enzymatic activity responsible for tissue damage in the reproductive tract (Lockwood et al. 1984, Thomford et al. 1996), the molecules of the protozoa involved in the colonization process, the persistence of infection, the protective immunity (Felleisen 1999), and the evasion mechanisms of the host immune response (Corbeil et al. 1991, Talbot et al. 1991, Granger \& Warwood 1996).

The interest for research on this intrinsic process of immunopathogenesis in the female has lead to search for animal models alternative to cattle to ease experimental designs and to make them cheaper. Different laboratory animals such as hamsters, guinea pigs and rabbits have been used as vaginal infection models with unsatisfactory results (Mac Donald et al. 1948, Maestrone \& Semar 1967, Kulda 1990). At present, the susceptibility of BALB/c mouse to the T. foetus vaginal infection has been proved, though the colonization has been difficult, requiring persistent estrogenization by means of either serial inoculations or estradiol implants (McGrory \& Garber 1992, St Claire et al. 1994). It has been shown that the mice treated with estrogen were infected at a higher percentage than those untreated (St Claire et al. 1994). Others authors have reported that reproductive tract lesions caused by T. foetus in the estrogenized mouse model are similar to those found in naturally infected cattle (Van Andel et al. 1996). They concluded that the mouse model might be useful to study the pathogenesis of this disease.

The treatment with estrogens raises the level of glucogen in the vagina and favours the initial T. foetus colonization (Corbeil et al. 1985). Although estrogens might be useful to the establishment of the vaginal infection, using high or repeated doses of estrogens produce undesirable health effects, such as purulent vaginal discharges, perivulvar abscesses, hyperkeratosis of vaginal epithelium and hydrometra (St Claire et al. 1994, Van Andel et al. 1996). The use of the model is limited by these consequences. It has been proved that the estrogen treatment may affect the immune response, because it increases the levels of uterine antibodies and decreases the antibody response in the vagina (Wira \& Sandoe 1987, 1989). Although it was difficult to infect non-estrogenized mice (St Claire et al. 1994), other investigators did not observe differences in the vaginal infection between estradiol-treated and untreated mice (Mutwiri \& Corbeil 1998). This has been attributed to the virulence of the T. foetus strain used in the experiments.

Apart from these difficulties, the mouse model shows promising results, though it is necessary to elucidate these contradictory aspects of different authors, in order to get a reliable and reproducible model. Therefore, a model without persistent estrogenization and with normal estrous cycles would be the most appropriate for further studies on pathogenicity mechanisms, immune response, molecular interaction in the hostparasite relationship and protective testing of future vaccines.

In this study, we have evaluated the establishment of vaginal infection with different $T$. foetus concentrations, its duration and 
variations in the stages of the estrus cycle. This has been carried out in a mouse model with synchronized estrus by means of previous administration of $\beta$-estradiol 3-benzoato (EB) and with natural estrus.

\section{MATERIALS AND METHODS}

Animals. Ninety seven BALB/c female mice (Breeding House, Facultad de Ciencias Veterinarias, UNCPBA), 6-8 weeks old, were housed according to the ANMAT rules (1996), with controlled temperature and air. Lighting was provided on a 12-h light/dark cycle, and food and water ad libitum.

Determination of the estrous cycle. All animals were examined prior to the vaginal cytologic smear practice (Allen 1922), to determine the stage of the estrus cycle. Samples of vaginal mucus were obtained by means of aspiration with a micropipette and discarded tips, with $5 \mathrm{ml}$ of sterile phosphate-buffered saline (PBS) previously instilled, $\mathrm{pH} 7.2$ and they were microscopically observed in a direct way at $10 \mathrm{x}$.

Once the estrus cycle was determined, mice were divided into two groups:

Group A: 47 animals in different stages of the estrus cycle.

Group B: 50 animals in natural estrus.

Estrus synchronization. The 47 animals in Group A were inoculated intramuscularly with $5 \mathrm{mg}$ of b-estradiol 3-benzoate (EB) suspended in $0.1 \mathrm{ml}$ of sterile sesame oil. In order to test the evolution of the estrus cycle, they were examined by means of vaginal cytologic smears 24 and 48 hours later.

Inoculum. Tritrichomonas foetus strain, isolated from a preputial sample, was cultured in Diamond's medium (1983) with agar (TYM), and subcultured into $50 \mathrm{ml}$ of TYM broth at $37^{\circ} \mathrm{C}$ during $48 \mathrm{~h}$. Afterwards, it was centrifuged at $3000 \mathrm{rpm}$ during 20 minutes, and the sediment was washed twice with sterile PBS at pH 7.2. Finally, protozoa were resuspended into PBS and their concentration was adjusted for the vaginal inoculum, according to the experimental subgroups of Groups A and B (Table 1).

Experimental design. Mice belonging to each group (A and $B$ ) were divided into five subgroups. They were individually identified with a notch code on their outer ears. Animals were inoculated intravaginally with $10 \mathrm{ml}$ of a $T$. foetus suspension, according to the concentration established for each subgroup (Table 1). In Group A, it was done 48 hours after EB treatment, and in Group B, it was done while assessing the natural estrus. Both groups were reinoculated 24 hours later with the same concentration of $T$. foetus corresponding to the design of each subgroup.

Table 1. Distribution of BALB/c female mice, in different subgroups, according to the intravaginal dose of Tritrichomonas foetus

\begin{tabular}{cccc}
\hline Subgroups & $\begin{array}{c}\text { Group } A^{\mathrm{a}} \\
(\mathrm{n})\end{array}$ & $\begin{array}{c}\text { Group B } \\
(\mathrm{n})\end{array}$ & Vaginal inoculum $10 \mu \mathrm{l}$ \\
\hline 1 & 9 & 10 & $0.1 \times 10^{6} \mathrm{Tf}$ \\
2 & 10 & 10 & $0.2 \times 10^{6} \mathrm{Tf}$ \\
3 & 10 & 7 & $0.5 \times 10^{6} \mathrm{Tf}$ \\
4 & 10 & 15 & $0.9 \times 10^{6} \mathrm{Tf}$ \\
5 & 8 & 8 & $1.5 \times 10^{6} \mathrm{Tf}$ \\
Total (n) & 47 & 50 &
\end{tabular}

a Group A: treated with â -estradiol 3-benzoate; Group B: selected group in natural estrous.

$\mathrm{b}(\mathrm{n})=$ number of animals.
Samples of vaginal mucus were taken weekly starting 7 days after intravaginal inoculation, from the whole number of animals belonging to Group A and B, during 34 weeks. Each sample was subjected to: a) microscopic observation recording presence or absence of T. foetus and vaginal cytologic smears in order to assess the stage of the cycle; b) cultured in Diamond's medium (TYM), to confirm the vaginal infection by means of protozoa isolation. The animals whose samples showed mobile protozoa with typical T. foetus morphological characteristics at direct observation, were considered infected ones. Negative samples to the microscopic observation were cultured into Diamond's medium at $37^{\circ} \mathrm{C}$ during 7 days and observed microscopically every 24 hours. After three consecutive weekly negative samplings at direct observation and culture, animals were considered free of vaginal infection.

Statistical analyses. Data were analyzed by means of Chi-square test and Fisher's exact test, using the PROC FREQ procedure of Statistical Analysis System, Version 8 (SAS, Institute Inc., Cary, NC, USA). Differences were considered to be statistically significant if $p<0.05$.

\section{RESULTS}

Effect of treatment with $\beta$-estradiol 3-benzoate on estrus cycle. Vaginal cytologic smear prior to treatment with EB showed that the 47 animals in Group A were at different stages of the estrus cycle. Forty-eight hours after treatment it was observed that 43 animals $(91.5 \%)$ were in estrus and 4 animals $(8.5 \%)$ in proestrus. At 5-7 days after treatment, estrogenic effect decreased allowing the animals to cycle regularly during the 34 weeks of the study (Fig.1).

Vaginal infection. Direct observation of vaginal mucus and culture on Diamond's medium showed that the total number of infected animals in Group A was higher than those in Group B from the first week post-infection and during the whole study.

Group A showed 44 infected animals (93.6\%) in the first week, maintaining the infection 29 of them $(61.7 \%)$ at the end of the assay (34 weeks). On the other hand, in Group B, 19 (38\%) and 12 (24\%) infected animals were detected at the 1 st and 34th week, respectively. Comparative results within the groups during the whole experimental period are summarized in Figure 2.

With the different intravaginal doses assayed in the subgroups of Group A and B, variations were obtained in the number of infected animals ranging from $87.5 \%$ to $100 \%$ in the

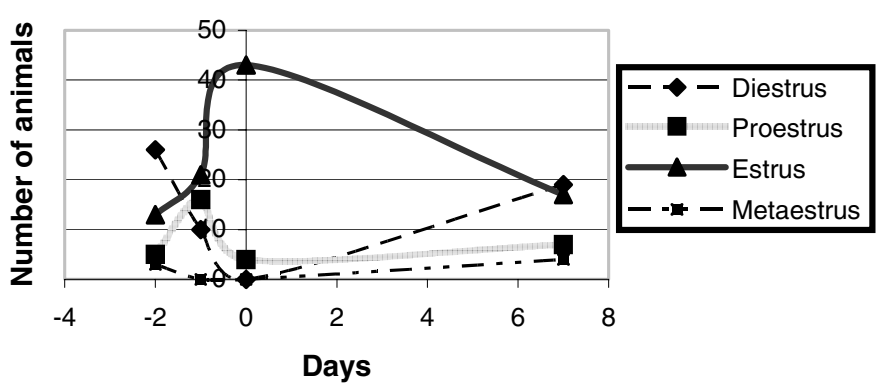

Fig.1. Dynamics of the total distribution of the stages of the estrus cycle of Group A mice $(n=47)$. Day - 2 : treatment with $\beta$-estradiol 3-benzoate. Day 0: intravaginal instillation with Tritrichomonas foetus. Day + 7: first week post-vaginal infection. 
first week post-infection for Group A, and from 25\% to $46.6 \%$ for Group B.

In both groups a gradual decrease in infected animals during the 34 weeks was observed. A variation in the persistence of the infection ranging from $44.4 \%$ to $80 \%$ for Group A subgroups and from $12.5 \%$ to $42.80 \%$ for Group B subgroups was detected at the end of the study. These results are summarized in Figure 3 and 4.

\section{Statistical analysis}

In order to evaluate whether or not the treatment with EB favored the establishment of vaginal infection, the number of infected animals in the first week after inoculation in each group was taken into account (Table 2). The Chi-square test showed highly significant differences between Group A and B results $(\mathrm{P}<0.0001)$.

The analysis of EB treatment effect on the persistence of vaginal infection was carried out taking only the number of infected animals at the first week after inoculation and how much of them maintained the vaginal infection until 34 weeks postinoculation (Table 3). By means of Chi-square test it was determined that there were no significant differences between the groups. $(\mathrm{P}=0.1097)$.

Fisher's exact test was used to assess whether the different doses of T. foetus administered were linked to the establishment

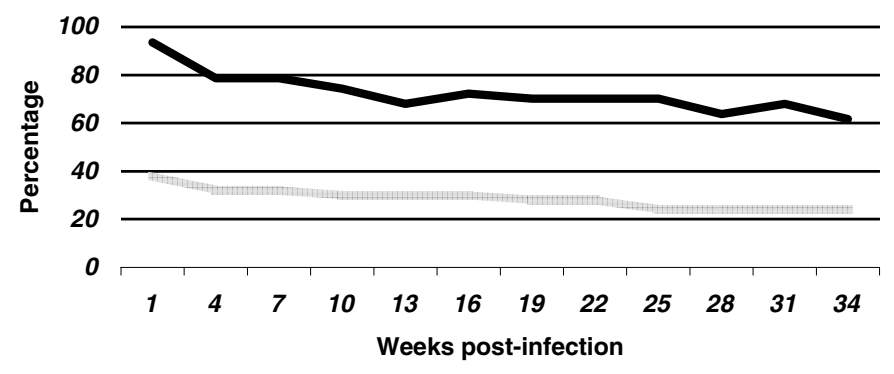

\begin{tabular}{ll}
\hline Group A & Group B \\
\hline
\end{tabular}

Fig.2. Dynamics of vaginal infection with Tritrichomonas foetus in female BALB/c mice during 34 weeks. Group A: animals treated with $\beta$-estradiol 3-benzoate. Group B: without treatment.

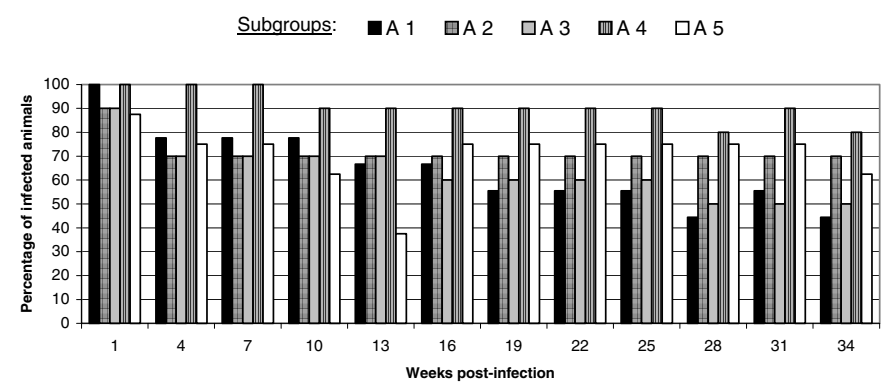

Fig.3. Dynamics of vaginal infection in female BALB/c mice, treated with $\beta$-estradiol 3-benzoate (Group A) and inoculated with different doses of Tritrichomonas foetus. Subgroups: A1: 0,1 $\times 10^{6}$

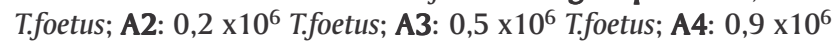
T.foetus; A5: 1,5 x10 $10^{6}$ T.foetus. of vaginal infection in each group showing that there were no significant differences between infecting doses $(\mathrm{P}=0.7718$ and $\mathrm{P}=0.8632$ for Group $\mathrm{A}$ and $\mathrm{B}$, respectively).

\section{DISCUSSION}

These results show that the mouse model with estrous synchronized by treatment with EB (Group A) had a higher number of animals with vaginal infection than Group B, which was inoculated in natural estrus. This finding differs from other authors who suggest persistent estrogenization to maintain vaginal infection (St Claire 1994, Hook et al. 1997, Van Andel et al. 1996). Mutwiri \& Corbeil (1998) did not observe differences between the estrogenized and the non estrogenized models, but they used as inoculum a suspension of Tritrichomonas foetus in the culture medium with $0.32 \%$ agar. Considering that the estrus in mice lasts about 12 hours and repeats every 5-7 days

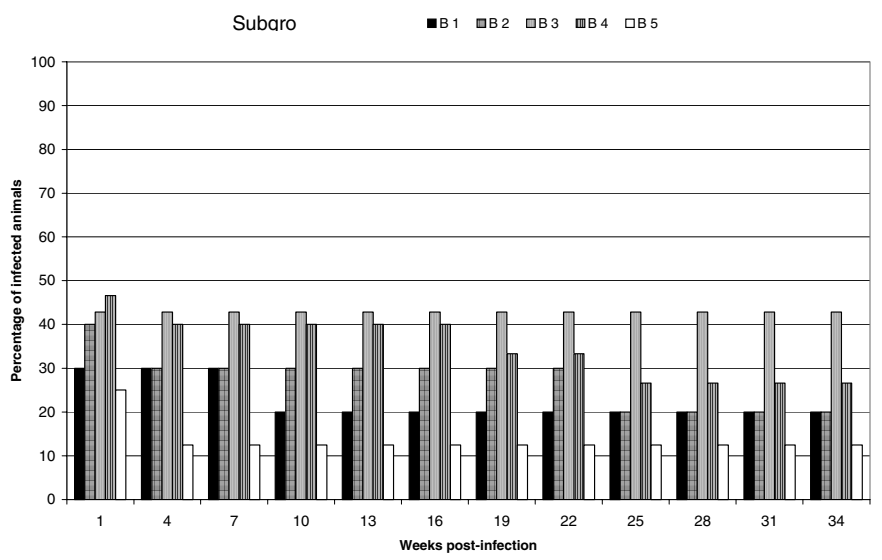

Fig.4. Dynamics of vaginal infection in female BALB/c mice, (Group B) and inoculated in natural estrus with different doses of Tritrichomonas foetus. Subgroups: B1: $0.1 \times 10^{6}$ T.foetus. B2: 0.2 x $10^{6}$ T.foetus. B3: $0.5 \times 10^{6}$ T.foetus. B4: $0.9 \times 10^{6}$ T.foetus. B5: 1.5 $\mathrm{x} 10^{6}$ T.foetus.

Table 2. Number of infected animals at the first week postintravaginal inoculation with Tritrichomonas foetus inGroup A and $B$

\begin{tabular}{cccc}
\hline Group $^{\text {a }}$ & Infected & Non infected & Total \\
\hline A & $44(93.6 \%)$ & $3(6.4 \%)$ & $47(100 \%)$ \\
B & $19(38.0 \%)$ & $31(62.0 \%)$ & $50(100 \%)$ \\
Total & $63(65.0 \%)$ & $34(35.0 \%)$ & $97(100 \%)$
\end{tabular}

a Group A: treated with â -estradiol 3-benzoate; Group B: untreated.

Table 3. Number of infected animals that maintained the vaginal infection at 34 weeks post-intravaginal inoculation with Tritrichomonas foetus

\begin{tabular}{cccc}
\hline Group $^{\text {a }}$ & Infected & Non infected & Total \\
\hline A & $29(65.90 \%)$ & $15(34.10 \%)$ & $44(100 \%)$ \\
B & $12(63.15 \%)$ & $7(36.85 \%)$ & $19(100 \%)$ \\
Total & $41(65.07 \%)$ & $22(34.93 \%)$ & $63(100 \%)$
\end{tabular}

a A: treated with $\beta$-estradiol 3-benzoate; B: untreated. 
(Allen 1992), the inoculum condition with a higher viscosity due to the agar may have influenced the maintenance of a number of viable protozoa during more than an estrus, allowing infection to establish at different times.

Taking into account that infection in cattle starts at the time of the estrus, this situation is an important condition for the reproduction of the disease in experimental models. During estrogenic influence the glycogen levels in the vaginal epithelium increase, being essential for the adherence of the protozoa and later colonization (Corbeil et al. 1985). To extend this natural estrogenic state, also affect the defense mechanisms of the host (Wira \& Sandoe 1987, 1989). Therefore, persistent estrogenization as a condition to achieve vaginal infection with $T$. foetus in $\mathrm{BALB} / \mathrm{c}$ mice, is inadequate for research of the mechanisms of pathogenesis, immune response and vaccine studies.

We had previously evaluated different concentrations of EB, in order to synchronize the estrus with lower doses and observed that a dose of $5 \mathrm{mg}$ of EB was the most appropriate one (Monteavaro et al. 2000). Therefore, on the basis of these results, $5 \mathrm{mg}$ of BE were used to synchronize estrus at 48 hours after treatment in this study. The animals in estrus decreased from the second day after synchronization, and they turned back to normal cycles by 5-7 days (Fig. 1). Establishment and persistence of infection did not alter estrus cycles during the 34 weeks.

This period of estrogenic influence was enough to allow protozoa to start vaginal adherence and colonization in Group A mice. On the other hand, Group B, not treated with EB and inoculated in natural estrus, does not offer to our opinion a sufficient receptive time for the initial colonization of the parasite. We consider this an important aspect that clearly explains the differences obtained between Group A and B (Fig.2), showing that treatment with EB had a positive effect in the establishment of vaginal infection, but did not influence the persistence of it.

With the different doses of the intravaginal inoculum assayed for both groups, it was seen that with any of the doses infection was established, although there were differences in the number of infected animals between doses. These differences were not linked to the higher or lower concentration of the inoculum. In Group A, Subgroup A1 with the lowest dose $\left(0.1 \times 10^{6}\right.$ T.foetus $)$

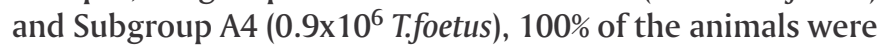
infected at the beginning of the assay and during the first 7 weeks Subgroup A5 with the highest dose $\left(1.5 \times 10^{6}\right.$ T.foetus $)$ showed a lower number of infected animals than A4 during the whole study, while the latter showed an homogenous percentage of vaginal infection during the 34 weeks (Fig.3).

In Group B, without treatment with EB, it was also observed that the number of infected animals was not linked to the concentration of the vaginal inoculum. For example, Subgroup B5 with the highest dose $\left(1.5 \times 10^{6}\right.$ T.foetus $)$ showed the lowest percentage during the whole study, Subgroup B3 $\left(0.5 \times 10^{6}\right.$ T.foetus) had a more homogeneous behavior with $42.8 \%$ of infected animals during the 34 weeks (Fig.4).

However, statistical analysis of the effect of the inoculum concentration in the establishment and persistence of the vaginal infection in each of the subgroups did not show significant differences $(\mathrm{P}>0.05)$. This differs from the results of other authors (St Claire et al. 1994) who observed that higher T. foetus concentrations resulted in longer persistence of vaginal infection. Hook et al. (1995) observed that lowering of the inoculum dose to $0.2 \times 10^{6}$ T. foetus affected the ability to initiate colonization of the genital tract in BALB/c mice.

Taking into account these aspects, we consider that the establishment and persistence of vaginal infection with $T$. foetus in this experimental model depend on factors inherent to the parasite-host relationship, for example, on the capacity of the protozoa to colonize, the presence of suitable receptors in the vaginal epithelium during the estrogenic phase of the cycle, and on the activation of the defense mechanisms of the host. Mutwiri \& Corbeil (1998) assessed the immune response of BALB/c mice infected intravaginally with T.foetus and observed that persistence was characterized by low levels of antibodies in the secretions of the reproductive tract. This low immune response may explain, in our study, the slow decrease in the number of infected animals during the 34 weeks (Fig.2) ending with a significant number of mice with intravaginal infection.

Therefore, on the basis of the results obtained, we present an experimental model without the adverse effects of permanent estrogenization with high and/or repeated doses. This model allows us to have a number of animals under the conditions required to start the establishment and persistence of vaginal infection with T. foetus, for experimental studies on mechanisms of pathogenecity, immune response, molecular interaction of parasite-host relationship, protective evaluation of different immunization agents and therapeutic effects of drugs.

Acknowledgements.- The authors thank Dr. Edgardo Rodríguez for his help with the statistical analysis. Financial support was provided by grants from SeCyT, Universidad Nacional del Centro de la Provincia de Buenos Aires, Tandil, Argentina.

\section{REFERENCES}

Allen E. 1922. The estrous cycle in the mouse. Am. J. Anat. 30:297.

Anderson M., BonDurant R.H., Corbeil R. \& Corbeil L.B. 1996. Immune and inflammatory response to reproductive tract infection with Tritrichomonas foetus in immunised and control heifers. J. Parasitol. 82:594-600.

ANMAT 1996. Reglamentación para Bioterios de Laboratorios Elaboradores de Especialidades Medicinales y/o Análisis de Terceros, Cap.I,II,II,IV,V. Disposición 6344, Administración Nacional de Medicamentos, Alimentos y Tecnología Médica. Cary, NC, USA..

BonDurant R.H. 1985. Diagnosis, treatment and control of bovine trichomoniasis. Comp. Cont. Ed. 10:179-188.

Clark B.L., Dufty J.H. \& Parsonson M. 1983. The effect of Tritrichomonas foetus infection on calving rates in beef cattle. Aust. Vet. J. 60:71-74.

Corbeil L.B., Chatterjee A., Foresman L. \& Westfall J.A. 1985. Ultrastructure of cyclic changes in the murine uterus, cervix and vagina. Tissue and Cell 17:53-68.

Corbeil L.B, Hodgson J., Jones D., Corbeil R., Widders P. \& Stephens L. 1989. Adherence of Tritrichomonas foetus to bovine vaginal epithelial cells. Infect. Immun. 57:2158-2167.

Corbeil L.B., Hodgson, J.L. \& Widders P.R.. 1991. Immunoglobulin binding by Tritrichomonas foetus. J. Clin. Microbiol. 29:2710-2714.

Diamond, L.S. 1983. Lumen-dwelling protozoa: Entamoeba, Trichomonads and Giarda, p.89-98. In vitro Cultivation of Protozoan Parasites. In: Jensen J.B. (ed.), CRC Press, Boca Ratón, Florida.

Felleisen R.S.J. 1999. Host-parasite interaction in bovine infection with Tritrichomonas foetus. Microb. Infect. 1:807-816. 
Goodger W.J. \& Skirrow S.Z. 1986. Epidemiologic and economic analyses of an unusually long epizootic of trichomoniasis in a large California dairy herd. J. Am. Vet. Med. Assoc. 189:772-776.

Granger B.L. \& Warwood S.J. 1996. Rapid internalization and degradation of surface-bound antibodies by Tritrichomonas foetus. J. Parasitol. 82:539-549.

Honigberg B.M. 1978. Trichomonads of veterinary importance, p.164273. In: Kreier J.P. (ed.) Parasitic Protozoa. Academic Press, New York.

Hook R.R., St Claire M., Riley L., Franklin C. \& Besch-Williford C.L.1995. Tritrichomonas foetus: comparison of isolate virulence in an estrogenized mouse model. Exp. Parasitol. 81:202-207.

Hook Jr R.R., St Claire M.C., Riley L.K., Franklin C.L. \& Bessch-Williford C.L. 1997. Mouse strain and age affect susceptibility to experimentally induced genital trichomoniasis. Lab. Anim. Sci. 47:324-326.

Kulda J. 1990. Employment of experimental animals in studies of Trichomonas vaginalis infection, p.112-154. In: Hornberg B.M. (ed.) Trichomonads Parasitic in Humans. Springer-Verlag, New York, NY.

Kunstler J. 1888. Sur quelques infusoires nouveaux oupeu connus. Comptes de l'Acadamie des Sciences, Paris, 107:953-955.

Lockwood B.C., North M.J. \& Coombs G.H. 1984. Trichomonas vaginalis, Tritrichomonas foetus and Trichomitus batrachorum: comparative proteolytic activity. Exp. Parsitol. 58:245-253.

MacDonald E.M., Nelson P.M., Byme H.J. \& Tatum A.L. 1948. Tritrichomonas foetus experimental infection in rabbits. J. Immunol. 59:295-300.

Maestrone G. \& Semar R. 1967. Experimental intravaginal infection with Tritrichomonas foetus in guines pigs. Chemotherapia 12:137-145.

McGrory T. \& Garber G. 1992. Mouse intravaginal infection with Trichomonas vaginalis and role of Lactobacillus acidophilus in sustaining infection. Infect. Immun. 60:2375-2379.

Monteavaro C., Echevarría H., Soto P. \& Catena M. 2000. Efecto del 3-benzoato de beta estradiol en el ciclo estrual del ratón. Jornadas Latinoamericanas de Fármaco-Toxicología Veterinaria, Fac. Cienc. Veterinarias, UNICEN, Tandil, Buenos Aires, vol.1, p.15.

Morgan B.B. 1944. Studies on the trichomonad carrier cow problems. J. Anim. Sci. 3:437.

Mutwiri G.K. \& Corbeil L.B. 1998. Genital and systemic immune response in a murine model of Tritrichomonas foetus infection. J. Parasitol. 84:321-327

Parsonson I.M., Clark B.L. \& Dufty J.H. 1976. Early pathogenesis and pathology of Tritrichomonas foetus infection in virgin heifers. J. Comp. Pathol. 86:59-66.

Rae D.O. 1989. Impact of trichomobiasis on the cow-calf producer's profitability. J. Am. Vet. Med. Assoc. 194:771-775.

Rhyan J.C., Wilson K.L. \& Burgess D.E. 1988. Fetal and placental lesions in bovine abortion due Tritrichomonas foetus. Vet. Pathol. 25:350-355.

SAS Institute 1989. SAS/STAT User's Guide. Vol.1. Version 6. Fourth edition. Cary N.C. (ed.). SAS Institute Inc. 943p.

Skirrow S.Z. 1987. Identification of trichomonad carrier cow. J. Am. Vet. Assoc. 191:553-554.

Skirrow S.Z. \& BonDurant R.H. 1988. Bovine Trichomoniasis. Vet. Bull. 58:591-603.

Skirrow S.Z. \& BonDurant R.H. 1990. Immunoglobulin isotype of specific antibodies in reproductive tract secretions and sera in Tritrichomonas foetus infected heifers. Am. J. Vet. Res. 51:645-653.

Soto P. \& Parma A.E. 1989. The immune response in cattle infected with Tritrichomonas foetus. Vet. Parasitol. 33:343-348.

Soto P., Monteavaro C., Echevarría H. \& Catena M. 1997. Evaluación de la patogenicidad de Tritrichomonas foetus. Revta Med. Vet., Local?, 78:146-149.

St Claire M.C., Riley L.K., Franklin C.L, Besch-Williford C.L. \& R.R. Hook Jr R.R. 1994. Experimental induced intravaginal Tritrichomonas foetus infection in the estrogenized mouse. Lab. Anim. Sci., Revista??? Local?!!, 44:430-434.

Talbot J.A., Nielsen K. \& Corbeil L.B. 1991. Cleavage of reproductive secretions by extracellular proteinases of Tritrichomonas foetus. Can. J. Microbiol. 37:384-390.

Thomford J.W., Talbot J.A., Ikeda J.S. \& Corbeil L.B. 1996. Characterization of extracellular proteinases of Tritrichomonas foetus. J. Parasitol. 82:112-117.

VanAndel R.A., Franklin C.L., St Claire M.C, Riley L.K, Besch-Williford C.L \& R.R. Hook Jr. 1996. Lesions of experimental genital Tritrichomonas foetus infections in estrogenized BALB/c mice. Vet. Pathol. 33:407-411.

Wira C.R. \& Sandoe C.P. 1987. Specific IgA antibodies in the secretions of the female reproductive tract: effects of immunization and estradiol on expression of this response in vivo. J. Immunol. 138:4159-4164.

Wira C.R. \& Sandoe C.P. 1989. Effect of uterine immunization and estradiol on specific $\operatorname{Ig} A$ and $\operatorname{IgG}$ antibodies in uterine, vaginal and salivary secretions. Immunol. 68:24-30. 